\title{
Dissecting Marriage Fraud as a True Immigration Crime
}

\author{
George S. Asllani \\ Annunziata \& Asllani, LLP, 6 Sherman Road, Farmingdale, NY 11735, USA; George.Asllani@gmail.com; \\ Tel.: +1-646-866-7878 \\ Academic Editor: Ingrid Eagly \\ Received: 12 November 2015; Accepted: 2 February 2016; Published: 24 February 2016
}

\begin{abstract}
Marriage fraud is considered a true immigration crime in that not only does it carry penalties related to an immigrant's status, but also severe penal consequences under federal law. This paper seeks to explore how a case of marriage fraud is discovered, investigated and prosecuted by immigration officials, and, ultimately, by the judicial system. The paper focuses on recent immigration law developments and lays out a blueprint of a marriage fraud case under the 1986 Marriage Fraud Amendments to the Immigration and Naturalization Act.
\end{abstract}

Keywords: marriage fraud; immigration law; criminal law; USCIS; citizenship; green card

\section{Introduction}

Marriage is a topic often reserved for state courts. Divorces, separations, and other matrimonial matters seldom appear in federal jurisdictions. Although in recent years federal courts have been becoming increasingly more involved in decisions regarding the constitutionality of laws that impact marriage, this paper does not seek to discuss or explore those subjects. There is one particular aspect of matrimony which is often brought in front of federal courts by virtue of federal law; that is immigration.

In immigration law, marriage plays a significant role since it is one of the quickest ways of achieving a highly desirable immigration status. By marrying a United States (US) citizen, an alien can obtain citizenship within three years of that marriage, as long as the alien remains married to the same US citizen. It becomes clear therefore that this highly desirable benefit is ripe for exploitation by those who intend to defraud the system. It is in this context that marriage becomes a federal matter and, furthermore, a concern of federal criminal law.

Congress has tried to minimize the risks of marriage fraud by enacting the 1986 Marriage Fraud Amendments to the Immigration and Naturalization Act. These amendments place restrictions upon using marriage to receive an immigration benefit. Therefore, when an alien marries a US citizen, the law requires the alien to file a joint petition requesting a benefit for the alien spouse, be subject to an initial interview and maintain a viable marriage with that same citizen until two years of marriage have passed. During the two-year period, the alien is given a two-year permanent resident card or green card. It is only after that two-year period that the alien files for removal of the conditions imposed, and if approved, receives a full 10-year green card.

While most of the process rests on administrative adjudications, referrals are made from the administrative realm to the criminal prosecution sphere. The United States Citizenship and Immigration Service (USCIS), Customs and Border Protection and Immigration and Customs Enforcement all have document fraud units or an equivalent, which handle suspected cases of marriage fraud. These units receive the referral from their administrative counterpart and launch an investigation to determine whether the marriage is bonafide or whether it was entered into with the purpose of 
evading immigration laws. If a determination is made that a fraud exists, the document benefit fraud unit will take one of two actions: (1) handle the matter administratively and deny the benefit without involving the criminal law; or (2) work with law enforcement and the US Attorney's Office to prosecute the fraud.

Marriage fraud is proscribed by law in the Immigration and Naturalization Act, codified at 8 U.S.C. $\S 1325$ (c) (2015). It subjects the offender to a maximum $\$ 250,000$ fine and a maximum of five years in prison. This section and its penalties apply not only to the US citizen but also to the beneficiary alien. Once a case reaches the US Attorney's Office, that office must begin preparing to try the case in front of a district judge or magistrate. Like any federal criminal prosecution, this involves constitutional rights as well as doctrines and laws of criminal procedure and criminal law. Post-conviction relief is available like any other criminal case. A marriage fraud conviction can be appealed to the Supreme Court.

In this paper I will discuss the current practices of prosecuting marriage fraud and its intricacies, comment on drawbacks, and recommend potential improvements that can be made to streamline this process. I will outline the delicate and complex process by which marriage fraud is defined, discovered, referred and, ultimately, investigated and prosecuted. I will discuss the types of investigations that are undertaken and the model used to prosecute marriage fraud. Also, I will discuss evidentiary and procedural issues that arise during a marriage fraud case. Lastly, I will discuss the consequences of a conviction for marriage fraud, and evaluate the overall state of the law as well as point out the detrimental aspects while recommending beneficial ones.

\section{The Process of Receiving Benefits through Marriage}

The source of marriage-based petitions comes from the Immigration and Naturalization Act ${ }^{1}$. Particularly, a US citizen may bestow an immigration benefit upon his or her spouse by petitioning the United States Citizenship and Immigration Service ${ }^{2}$. This category of petitions places the alien under the "immediate relative" category. This essentially means that an alien who is petitioned for by a US citizen, and falls in the "immediate category", does not have to wait for a nonimmigrant visa to become available ${ }^{3}$. This avenue is one of the quickest ways of obtaining an immigration benefit but it is also a strictly governed category, for it is where fraud often occurs. Although Lawful Permanent Residents are also able to petition their alien spouses, and grant upon them an immigration benefit, the law does not define those alien spouses as immediate relatives, and as such makes them subject to the allocated number of immigrant visas under that specific relationship (preference) category ${ }^{4}$. This paper only addresses fraud in the context of the immediate relative category.

To start the process, a petition (USCIS form I-130 Petition for Alien Relative) is filed with the appropriate field office of the United States Citizenship and Immigration Services ${ }^{5}$. The petitioner citizen and the alien spouse must submit documentation that proves their status. The citizen must show that she is in fact a citizen (either by birth or by naturalization) and then the couple must show some initial evidence that their marriage exists and that it is bonafide. This is documented by showing a marriage certificate, any previous divorce judgments, joint ownership or property documentation, joint lease, co-mingling of financial resources, and birth certificates of children of the marriage ${ }^{6}$.

$1 \quad 8$ U.S.C. $\S 1154$ (2015) and 8 U.S.C. $\S 1151$ (b) (2015) (stating that certain aliens are not subject to a numerical quota and that one such category of aliens are foreign spouses of US).

28 U.S.C. $\$ 1154(\mathrm{a})(\mathrm{II})$

322 C.F.R. $\S 42.21$ (2016) (stating "an alien who is a spouse or child of a United States citizen, or a parent of a US citizen at least 21 years of age, shall be classified as an immediate relative under INA § 201(b) (2012)").

$4 \quad 8$ U.S.C. § 1154(a) and 8 U.S.C. §1153(a)(2) (2015) (stating that a LPR may petition for his or her spouse, but that such petition is subject to the numerical visa allocations designated by Congress for that preference category). For a more in-depth treatment of family immigration categories, and rights of noncitizens in the US, please read [1].

5 See [2]. Form I-130 is used to establish general eligibility with the USCIS for receiving an immigration benefit based on a familial relationship.

6 USCIS instructions to form I-130 state that some documents to prove the relationship exists are: marriage certificate, joint ownership of property, children of the marriage, etc. 
Once the petition has been approved by the USCIS, and the alien spouse is in the United States, the approved spouse can apply for adjustment of status ${ }^{7}$. This essentially is the process of receiving a permanent resident card (also known as a green card). Within 90 days of filing USCIS form I-485, the spouse and US citizen will be subject to a personal interview by an immigration official ${ }^{8}$. This is the first administrative step towards deterring fraud. The official will verify the details that were provided in the application and test the couple on the veracity of their statements ${ }^{9}$. This simply entails a process where the couple will be asked questions the answers to which "any other married couple" would know about each other.

If the interview is successful, the alien spouse becomes approved and their status is adjusted to Conditional Permanent Resident. In 1986, the Marriage Fraud Amendments created the conditional residency ${ }^{10}$ status. Before the Marriage Fraud Amendments, the only available test to scrutinize the marriage was derived from Bark $v$. INS which set forth the principal that a "marriage is sham if the bride and groom did not intend to establish a life together at the time they were married"11. Under the Marriage Fraud Amendments, the conditional residency makes the alien spouse subject to further limitations. The spouse must remain married to the petitioning (sponsoring) US citizen for a period of two years, after which the alien spouse must file the form I-751 Petition to Remove Conditions, which must be filed jointly with the spouse to show that the marriage is still viable ${ }^{12}$. If a second interview is required (sometimes it is not), the couple will again be tested as to the bonafides of their marriage. If this second interview is successful, the alien spouse's conditions are lifted and they will receive a full 10-year green card. If he or she remains married to that same US citizen for one more year, he or she will become eligible for naturalization ${ }^{13}$.

\section{Discovery, Referral and Investigation of Marriage Fraud}

Marriage fraud is codified at 8 U.S.C. §1325(c) (1996) stating that "[a]ny individual who knowingly enters into a marriage for the purpose of evading any provision of the immigration laws shall be imprisoned for not more than 5 years, or fined not more than $\$ 250,000$, or both." 14 This codification is the baseline charge for prosecutors in federal courts across the nation. However, the administrative process often serves to discover the initial fraud and either refer it for prosecution or address it administratively.

The fraud detection process works in many ways, but according to the US Government Accountability Office ${ }^{15}$ it can best be described like this: First, either the USCIS service centers or field offices receive an application with supporting documentation for processing; if any suspicion arises at this point, the case is referred to the Office of Fraud Detection and National Security (FDNS). The USCIS service centers are required to report 100 percent of the articulable fraud to the FDNS ${ }^{16}$.

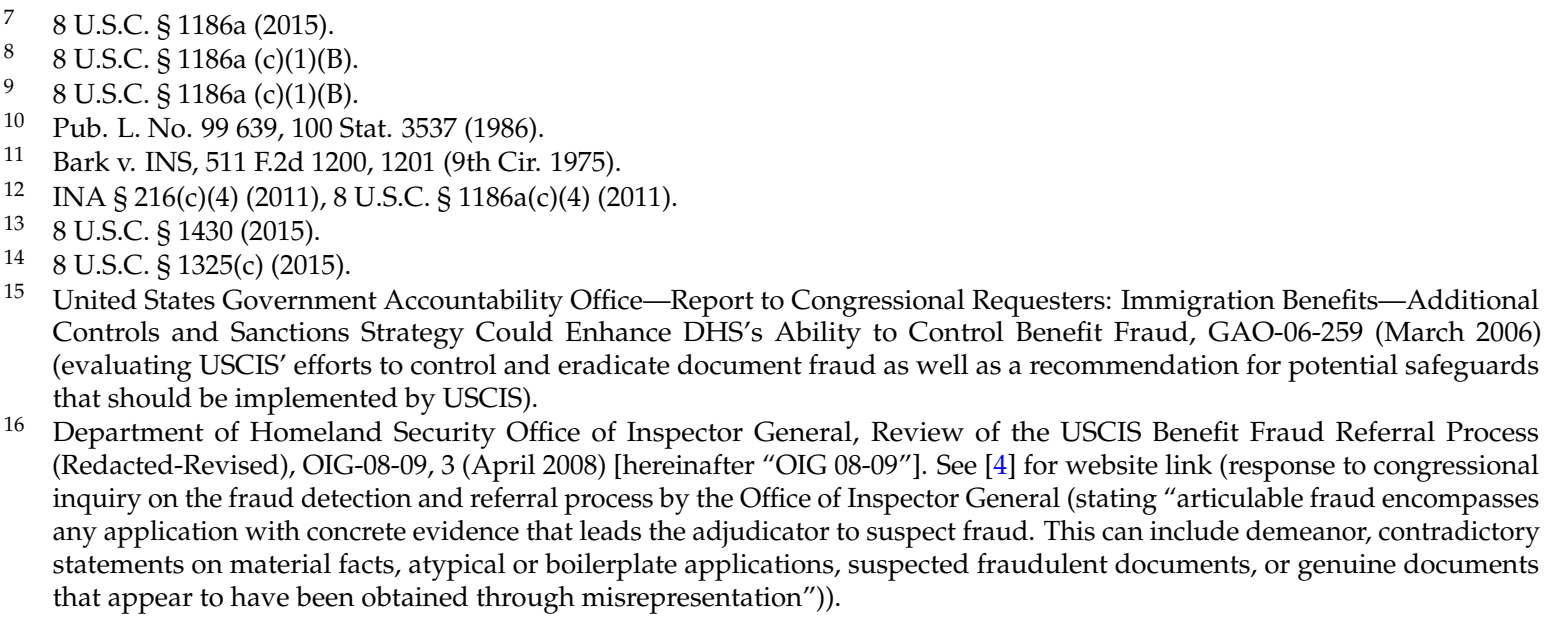

16 Department of Homeland Security Office of Inspector General, Review of the USCIS Benefit Fraud Referral Process (Redacted-Revised), OIG-08-09, 3 (April 2008) [hereinafter “OIG 08-09"]. See [4] for website link (response to congressional inquiry on the fraud detection and referral process by the Office of Inspector General (stating "articulable fraud encompasses any application with concrete evidence that leads the adjudicator to suspect fraud. This can include demeanor, contradictory statements on material facts, atypical or boilerplate applications, suspected fraudulent documents, or genuine documents that appear to have been obtained through misrepresentation")). 
This office internally forwards the case to its Fraud Detection Unit or the Field Anti-Fraud Unit (which serves as the on-the-ground arm of the USCIS for on-site visits to eradicate fraud $)^{17}$.

At the USCIS level, if the immigration officers do not find articulable fraud, they have the power to issue (1) an administrative denial; (2) a notice to appear for the couple; or (3) a request for further evidence ${ }^{18}$. However, if articulable fraud is found, the immigration officers must refer the case to FDNS which also reevaluates the evidence for articulable fraud and either forwards the case to US Immigration and Customs Enforcement or returns it back to USCIS for further review or administrative adjudication ${ }^{19}$.

Once the possible fraud is evaluated and needs more serious consideration, it will be referred to the law enforcement arm of the Department of Homeland Security, Immigration and Customs Enforcement or ICE. ICE maintains its own Benefit Fraud Unit that serves as the first line of evaluation of the fraud referred from USCIS. If the cases referred are not accepted, the Benefit Fraud Unit declines the case and brings it back to the USCIS/FDNS for administrative adjudication. If the Benefit Fraud Unit decides to accept the case, the investigation is referred to the office of the Special Agent in Charge that covers that particular region. Currently, there are 18 Special Agent in Charge offices or SACs across the nation [3]. The SACs take the referrals that result from the administrative process and investigate them ${ }^{20}$. This includes an in-depth review of the application with on-site verifications and visits.

The final step is the referral to the US Attorney's Office (USAO) that oversees the region for prosecution. ICE needs to consider the prosecutorial guidelines of each USAO and decide whether they should refer the case to that office. According to the Office of the Inspector General Review of the USCIS Benefit Fraud Referral Process, "about half of the 94 US Attorney Offices require a major organized conspiracy or criminal activities to consider prosecution, and more than half of those remaining had no guidance or said they accepted on a case-by-case basis." ${ }^{21}$ It becomes clear that only select cases are prosecuted, and this may very well be one of the reasons that marriage fraud slips through the proverbial cracks. Once a case is referred and selected for prosecution, the US attorney must prepare the case just like any other criminal proceeding.

\section{Prosecuting Marriage Fraud}

Prosecutors have two basic options for prosecuting marriage fraud. One is the use of 8 U.S.C. § 1325(c) (1996), namely the marriage fraud statute. Another option is the use of 18 U.S.C. § 1546 (2012), which proscribes the use of false statements under oath in an application for an immigration benefit ${ }^{22}$. Essentially, the latter statute is violated when the alien spouse, the US citizen, or both claim under oath in their applications that they are not entering a marriage for the purpose of evading immigration laws.

In preparing to make their case, the prosecutor has at their disposal the investigative grand jury and may decide to perform an additional investigation of witnesses and co-conspirators. As stated above, rarely does the US Attorney's Office accept a case that does not involve some sort of large-scale conspiracy. For all intents and purposes, this seems to mean that cases of single-instance marriage fraud are rarely prosecuted criminally, but rather addressed within the administrative process that was discussed in the previous section of this paper.

17 OIG 08-09 at 1. FDNS seeks to "(1) Obtain from adjudicators all petitions with objective fraud indicators, or articulable fraud, and refer these petitions to United States Immigration and Customs Enforcement (ICE) Office of Investigations for review; (2) develop a database to enhance FDNS' ability to analyze fraud; (3) track all petitions with articulable fraud indicators from referral to completion; and (4) identify and analyze fraud patterns and trends using data mining and pattern recognition to search new immigration petitions against known fraud indicators.".

OIG $08-09$ at 8 .

US v. Ortiz-Mendez, 634 F.3d 837, 838 (5th Cir. 2011).

OIG 08-09 at 10 (citing an ICE survey).

18 U.S.C. § 1546 (2015). 
A few words must be said about the witnesses in prosecutions for marriage fraud. Often during trial, the government will present the testimony of one of the spouses against the other ${ }^{23}$. It is often the US citizen spouse who testifies against the alien spouse ${ }^{24}$. It seems that this trial strategy works well since the testimony, coupled with other evidence, will often be sufficient to prove the marriage fraud beyond a reasonable doubt. However, this type of testimony brings about substantive and procedural issues that will be discussed in detail further below.

Under 8 U.S.C. $\S 1325$ (c) the prosecution must prove three elements beyond reasonable doubt ${ }^{25}$. First, the prosecution must prove that the alien knowingly entered into a marriage; second, that the marriage was entered into for the purpose of evading a provision of immigration law; and third, that the alien knew or had reason to know the immigration laws ${ }^{26}$. While both the US citizen and the alien are subject to the penalties and sanctions of the statute, this paper uses as a descriptor only the term "alien", while reminding the reader that the term US citizen can be used interchangeably within the charge ${ }^{27}$.

\section{The Elemental Breakdown of 8 U.S.C $§ 1325(c)$}

The first element of the crime requires demonstrating that the alien knowingly entered a marriage ${ }^{28}$. This is easily satisfied and does not pose an issue in most prosecutions. No reportable case law challenging the first element of the statute could be found. Conversely, there are cases where no challenges were made ${ }^{29}$. The mere fact of voluntarily entering into a marriage would satisfy the first element of the offense, specifically the "knowingly" aspect. A prosecutor would need only to show a marriage certificate to prove this. A notable aspect of this first element is the double standard that seems to only benefit the prosecutor. The alien cannot use his marriage license as proof of satisfying immigration requirements or as a defense against a charge for a sham marriage, while the prosecutor seems to be able to use that very same, otherwise irrelevant, document to the alien's detriment ${ }^{30}$.

The second element of the crime is that the alien entered the marriage in an attempt to evade the immigration laws. Essentially, the government must introduce evidence that speaks to the state of mind of the defendant in entering the marriage. The test used is subject to a split in the federal circuits ${ }^{31}$. The Sixth, Seventh and Tenth circuits ask: did the defendant marry to evade immigration laws ${ }^{32}$ ? Conversely, the First, Eighth, and Ninth circuits require that the government prove that the defendant "did not intend to establish a life with his spouse" ${ }^{\prime 3}$. Under the first standard, "the government needs to show that the goal of evading the immigration laws motivated the defendant." ${ }^{34}$ Under the latter standard, the viability of the marriage at its inception is crucial to the analysis ${ }^{35}$. Regardless of which

23 See US v. Islam, 481 F.3d 1125 (10th Cir. 2005); US v. Chowdhury, 169 F.3d 402 (6th Cir. 1999); US v. Ortiz-Mendez, 634 F.3d 837 (5th Cir. 2011); US v. Darif, 446 F.3d 701 (7th Cir. 2006).

24 See Generally Chowdhury, Ortiz-Mendez, and Darif. In each case, the US citizen spouse offered testimony at trial against the alien spouse (defendant).

25 See Islam, 481 F.3d 1125. In a scheme for marriage fraud, Crystal Mae Porter-Jamil organized numerous marriages between Pakistani males and US citizen females. Defendant was from New York and the spouse was from Kansas. After filing several bonafides with the USCIS, including joint tax returns, bank account statement and a cell phone bill, the defendant was charged with violating 8 U.S.C. $\$ 1325(\mathrm{c})$.

26 See Islam, $481 \mathrm{~F} .3 \mathrm{~d} 1128$.

27 See 8 U.S.C $\S 1325$ (c) (the statutory language is "any individual" which includes the alien spouse or the US citizen spouse).

28 Islam, 418 F.3d at 1128.

29 See US v. Rojas, 349 Fed. Appx. 467 (2009); US v. Magee, 315 Fed. Appx. 882 (2009) (in both cases, neither defendants dispute the first element of knowingly entering into a marriage. The respective courts clearly point this out in both cases as satisfying that element).

30 US v. Elzahabi, 517 F. Supp.2d 1121, 1124 (D. Minn. 2007) (stating that formal validity (i.e., marriage license, state licensure requirements) of defendant's marriage is immaterial to marriage fraud). See also, US v. Diogo, 320 F.2d 898, 905 (2nd Cir. 1963).

31 Ortiz-Mendez, 634 F.3d 837.

Ortiz-Mendez, 634 F.3d 839

3 Ortiz-Mendez, 634 F.3d 839.

[5] (citing from US v. Darif, 466 F.3d 701, 710 specifically discussing the two tests that have caused the split in the circuits).

5 US v. Orellana-Blanco, 294 F.3d 1143 (9th Cir. 2002). 
test a court adopts, the below listed factors can be used to either bolster or detract from determining the existence of intent to evade immigration laws.

A factor used to prove this element is the period of time in which the two spouses knew each other. In US v. Islam, the defendant, a Pakistani male, married a US citizen as a result of an arrangement by a third party. They had only known each other for a couple of days ${ }^{36}$. The court held that "a rational juror could easily find, based upon the evidence presented at trial that Defendant entered into a marriage with [her US citizen spouse] Herbert for the purpose of evading the immigration laws." ${ }^{\prime 37}$ In US v. Orellana-Blanco, the defendant, an El-Salvadorian male, married Beatrice Bohem after knowing her for only one day ${ }^{38}$. In US v. Darif, the defendant was abroad in Morocco when his bride-to-be, Ms. Dianna Kirklin, flew there to marry him. Kirklin married the defendant ten days later $^{39}$.

A second and very compelling factor is money in return for the marriage. In Darif, the third party who arranged the marriage between the defendant and the US citizen gave the latter $\$ 1000$, with $\$ 2000$ more to be paid once the US citizen married the defendant ${ }^{40}$. In US v. Chowdhury, the defendant paid $\$ 1000$ to the US citizen spouse to be paid in part when they wed, and in part after they attended the immigration interview ${ }^{41}$. In US $v$. Dimitrova, the defendant's father paid a US citizen $\$ 10,000$ to marry his daughter ${ }^{42}$. Under either circuit test, this factor plays an extremely important role, since it can both show that the defendant did not intend to establish a life with the spouse and that the marriage was motivated by a desire to evade immigration laws.

The proximity in time between the expiration of current immigration status and the marriage has also played a role in allowing an inference to be made by the jury in determining whether a marriage was entered into for purpose of evading the immigration laws. In Dimitrova, the defendant married a US citizen only 28 days before the expiration of her student visa ${ }^{43}$. In Islam, the defendant married a US citizen "weeks prior to the expiration of his authorized stay" in order to procure legal status in the US ${ }^{44}$.

Additionally, the motivation to evade an immigration law provision can be bolstered by showing that the alien spouse was at risk of deportation or in deportation proceedings. In Orlleana-Blanco, the situation was quite complicated. The defendant had entered the US illegally and was subject to deportation; however, because he was a class member in a civil lawsuit, his deportation had been deferred ${ }^{45}$. It was during this pendency that the defendant married a US citizen and applied for an immigration benefit. In Chowdhury, the defendant had entered the US with a two-month visa and had been denied an application for asylum, yet he had been granted a withholding of deportation ${ }^{46}$. During this period of time, the defendant married a US citizen and filed a petition for an immigration benefit.

The consummation of the marriage has also been used as evidence to bolster or detract from the intent requirement of the second element of the marriage fraud statute. Where no consummation of the marriage occurs, an inference is that the couple did not intend to live as husband and wife. In US $v$. Magee, the US citizen was subject to prosecution and she testified on her own behalf that the purpose of

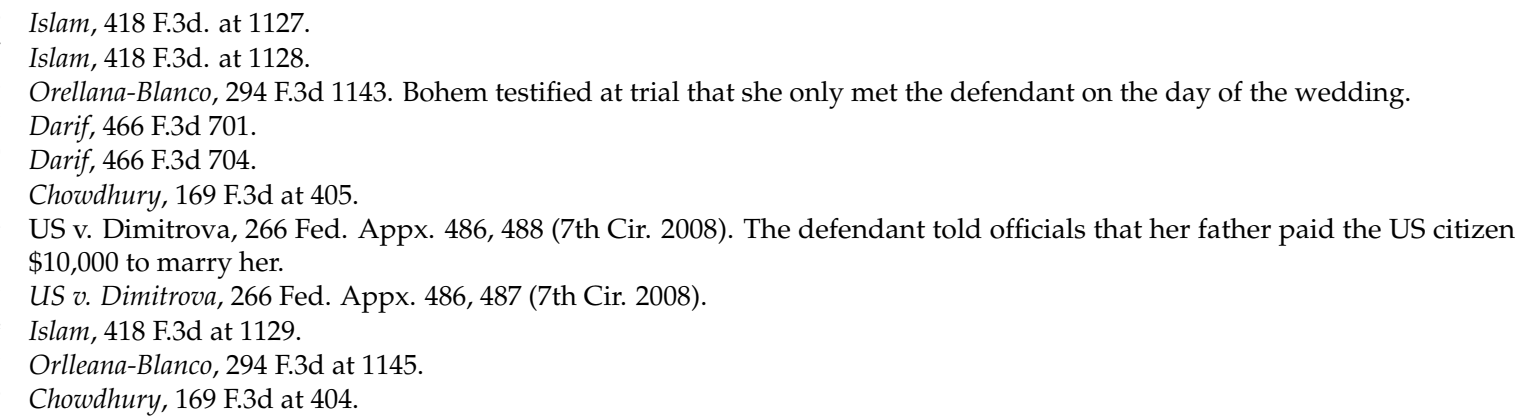


the marriage was so that her alien spouse would remain in the country ${ }^{47}$. Importantly, the defendant testified also that she "never had an intimate relationship with him, and never intended to live with him as husband and wife" 48 . In Chowdhury, the putative US citizen wife testified against her alien spouse that they never consummated the marriage notwithstanding opposing testimony by the defendant that they had sex on two occasions post-marriage ${ }^{49}$. In Ortiz-Mendez, Antonio Rosales, the US citizen spouse, testified against his putative alien wife that they "had never lived together as husband and wife, never slept in the same bed, and had never kissed, let alone have marital relations" 50 .

All of the above factors have often been used to prove the second element of the marriage fraud statute. Whether a court uses the "Establish a life together" test, or the "Evading immigration laws" test, the abovementioned elements can serve as a sword of the prosecutor or as a shield of the defense attorney.

The third element of the offense is that the alien knew or had reason to know the immigration laws. The test used to prove this element is one of knowledge of doing something that the defendant knows the law forbids. Specifically, and drawing from a Supreme Court decision in Bryan v. United States, the Court in Chowdhury stated:

[T] he government must prove more than the defendant's knowledge of the facts that constitute the offense, as is required by a statute punishing knowing violations of the law. However, in showing that the defendant knew his conduct was unlawful, the government need not prove that the defendant knew the specific law being violated ${ }^{51}$.

Therefore, the prosecution need only show that the defendant acted knowing that his conduct was unlawful ${ }^{52}$. The court in Islam echoed this by holding that particular knowledge of the specific immigration statute is not necessary ${ }^{53}$. It has been held that "facts and circumstances giving rise to an inference that the defendant knew he was violating the law" is sufficient to satisfy the third element of the marriage fraud statute ${ }^{54}$.

The facts and circumstances described above come in many shapes and forms. In Islam, the jury heard that the defendant generated paperwork to substantiate the marriage only after investigators had questioned his putative US citizen wife regarding the validity of the marriage $\mathrm{e}^{55}$. On review, the court held that a reasonable jury could have inferred that the defendant had reason to know or knew he was violating immigration laws. Similarly, in US $v$. Yang, the jury heard that the defendant traveled to China and staged an engagement party, in order to produce photographic evidence to substantiate the relationship ${ }^{56}$.

\section{A Word on Spousal Privilege}

This section of the paper discusses an issue that can arise during a trial for marriage fraud. The trial attorney, whether as a prosecutor or defense counsel, must be aware of this issue in order to perform their job thoroughly and in the best interest of their respective clients.

An issue that presents itself during marriage fraud trials, and that is worth discussing, is that of spousal privilege. Spousal privilege comes in two forms: (1) spousal communication privilege; and (2) spousal testimonial privilege. The spousal communication privilege protects "information

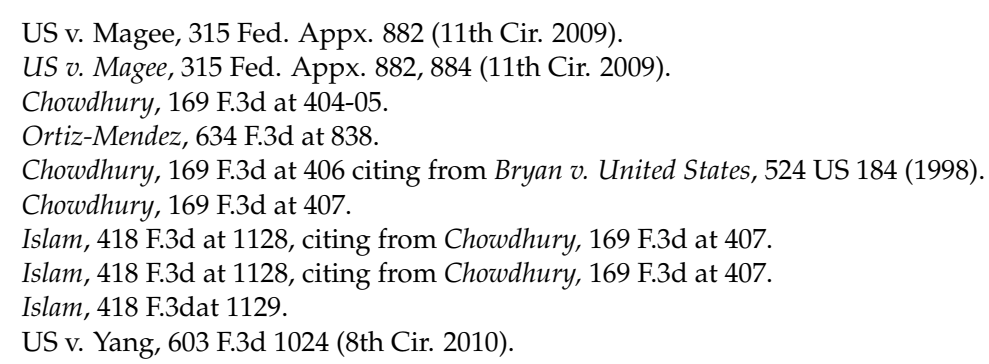


privately disclosed between husband and wife in the confidence of the marital relationship"57. The spousal testimony privilege protects spouses from being compelled to testify against each other in criminal proceedings ${ }^{58}$.

As stated above, trials for marriage fraud commonly involve one spouse testifying against the other. In Darif, the defendant sought to exclude certain letters to his putative citizen wife where he told her what to say to immigration officials regarding their sham marriage ${ }^{59}$. The privilege was held inapplicable by the court because it considered the defendant and the putative wife as joint participants in the criminal enterprise, namely the marriage fraud ${ }^{60}$. The court citing from US $v$. Westmoreland held that the privilege "applies only to communications made in confidence between the spouses during a valid marriage" 61 .

\section{Conclusions}

This conclusion evaluates three aspects of the marriage fraud process. First, it evaluates the current state of the administrative process of handling a marriage fraud case. Second, it discusses the criminal law procedure and substance of a marriage fraud case. Third, the conclusion comments on and evaluates the current state of state of affairs as it pertains to marriage fraud prosecutions with a personal note on policy and results.

\subsection{The Administrative Process}

As stated earlier in this paper, the administrative process is laden with bureaucratic structures that seem to hinder the process more than help to extract those cases that are truly fraudulent, in an expedient and efficient manner. As of this writing, there are two agencies which handle a fraud case before it ever reaches the US Attorney's Office for prosecution. The USCIS and the ICE agencies both have sub levels where a case must first be subject to evaluation in order to proceed further. While it cannot be argued that oversight is absolutely necessary in investigating and referring the fraud for prosecution, it seems unnecessary to undergo a multitude of steps to achieve a result which could be achieved with a more concise procedure. One step that should be taken in this direction is the elimination of the FDNS office, which handles fraud cases within the USCIS. With the removal of this bureaucratic office, the cases of fraud that can be articulated by the immigration officer who first reviews the case can be directly referred to the ICE agency for proper review and investigation.

At the ICE level, the bureaucratic and burdensome sub-division of duties continues. There are currently two sublevels of investigation within ICE that handle marriage fraud cases: the Benefit Fraud Unit and the Special Agent in Charge offices, which ultimately take the case based on geographical location. It is wasteful to maintain a Benefit Fraud Unit that essentially re-evaluates the work of the USCIS to determine whether the fraud exists. By streamlining the process directly to the Special Agent in Charge from the USCIS, any fraud can be revealed in a more efficient way. The office of the Special Agent in Charge can conduct field investigations and produce the wanted result while saving resources.

The resources that would be saved in eliminating this unnecessary bureaucratic process would reduce the backlog of immigration cases and, therefore, allow for a shorter period of wait time for immigration benefits. This course of action would force the agencies to reform their current policies of detection and referral by using more objective and articulable factors, which could be applied uniformly to cases in order to achieve the desired result of detecting and preventing fraud.

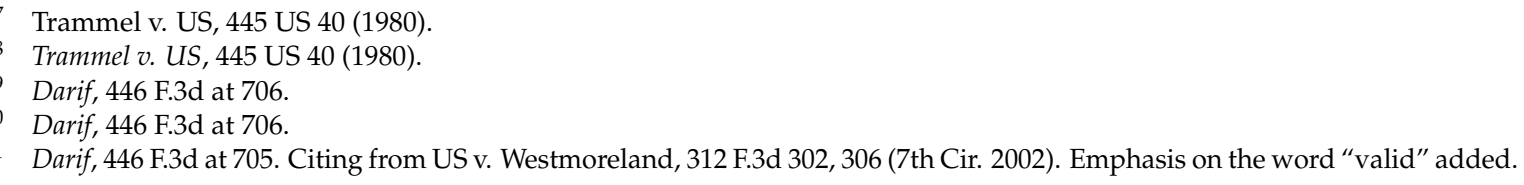




\subsection{The Substantive Charge of Marriage Fraud}

The Marriage Fraud Amendments have been in existence since 1986 and seem to be accepted by most as a helpful tool in deterring and preventing marriage fraud. While this might be true, an important issue to recognize is the scrutiny that marriages receive in immigration proceedings. An investigation into a marriage, which is used as a basis for receiving an immigration benefit, can involve interviews about intimate details of the union, and documentation that "traditionally" proves a legitimate marriage as well as imposing other hurdles that may prove difficult even for a bonafide marriage to overcome.

In looking at the elements of the marriage fraud statute, the current interpretation of the second element of the statute is of serious concern. More so is the approach of the Sixth, Seventh and Tenth circuits which test whether the defendant entered the marriage to evade immigration laws. As seen above, this strict test requires an invasive investigation of the marriage such as whether the marriage is consummated. Fundamental privacy rights are threatened each time this type of inquiry is conducted.

In using either of the tests, by requesting evidence that portrays a traditional marriage, courts risk creating an ostracizing effect for those marriages that do not conform to the standard. Different cultures may have different ideas of what marriage is, and how married couples are to conduct themselves. More importantly, these ideologies might be conflicting with the Western idea of traditional marriages. The spirit of American immigration includes a fundamental acceptance of different cultures and a level of respect for those differences both in culture and in law. When courts test marriages against a standard that juxtaposes a "traditional" marriage as seen through an American lens against a "questionable marriage", they dampen that spirit and enlarge the gap between cultural differences under immigration law. It is clear that the approach used by the First, Eighth and Ninth circuits, which requires that the government prove that the defendant did not intend to establish a life with his spouse, is better suited for the inquiry. This test seems appropriate in that it accommodates the needs of the non-traditional marriage. By adopting this test, courts are more likely to be less threatening to the fundamental right to marriage and the fundamental right to privacy, while promoting integrity in the immigration system.

\subsection{Overall Effects and Application}

The overall effect of the current immigration procedure for adjudicating, referring, investigating, and ultimately prosecuting marriage fraud is burdensome, bureaucratic and inefficient. This trend has created a ripple wave of lengthy application wait-times, over-burdened immigration administrators and courts, and ultimately a lack of deterrence of immigration benefit fraud.

One need not look further then recent newspaper articles to see the failings of the system in deterring immigration fraud. A Google search of newspapers nationwide (both print and online) produced a large amount of articles that report convictions or arrests for marriage fraud. For the most part, the articles speak of schemes, which involve more than one couple [6]. This resonates with the findings of this paper which reports that about $94 \%$ of all cases that are prosecuted by US Attorney Offices involve a large scheme of marriage fraud versus a single instance one.

With this data in mind, it is clear that the system needs administrative remedies to supplant the lack of sanctions for single-instance marriage fraud occurrences. These instances are either slipping by undetected or not being dealt with harshly enough to deter future occurrences. By trimming the agencies as suggested in the first part of this conclusion, the immigration system would be better able to refocus their resources in deterring marriage fraud by implementing strong and swift administrative sanctions for violators.

Conflicts of Interest: The author declares no conflict of interest. 


\section{References and Notes}

1. María Pabón López. “A Tale of Two Systems: Analyzing the Treatment of Noncitizen Families in State Family Law Systems and Under the Immigration System." Available online: http:/ /ssrn.com/abstract=1211262 (accessed on 6 January 2016).

2. Official Website of the United States Citizenship and Immigration Services. "I-130, Petition for Alien Relative." Available online: http:/ / www.uscis.gov/I-130 (accessed on 22 February 2016).

3. Official Website of the US Immigration and Customs Enforcement. "Identity and Benefit Fraud." Available online: http:/ /www.ice.gov/document-benefit-fraud/ (accessed on 22 February 2016).

4. Official Website of the Department of Homeland Security. "Department of Homeland Security Office of Inspector General, Review of the USCIS Benefit Fraud Referral Process (Redacted-Revised)." Available online: https://www.oig.dhs.gov/assets/Mgmt/OIGr_08-09_Apr08.pdf (accessed on 22 February 2016).

5. Marcel de Armas. "For Richer or Poorer or Any Other Reason: Adjudicating Immigration Marriage Fraud Cases within the Scope of the Constitution." Journal of Gender, Social Policy E the Law 15 (2006): 743.

6. Google.com/news-Keyword search with the terms "marriage fraud" with the date range of 1 January 2015-22 February 2016 produced several results including this: December 2011 the New York US Attorney's office for the Southern District arrested over twenty people who were involved with the smuggling of Eastern European women into the US for purposes of working them as adult entertainers. These women were made legal residents by arranged marriages with pre-selected US citizens. Available online: http://www.cnn.com/2011/11/30/justice/new-york-strip-club-charges / (accessed on 22 February 2016).

(C) 2016 by the author; licensee MDPI, Basel, Switzerland. This article is an open access article distributed under the terms and conditions of the Creative Commons by Attribution (CC-BY) license (http://creativecommons.org/licenses/by/4.0/). 